\title{
Investigation of a Spin-Torque Oscillator using Material with Negative Magnetic Anisotropy
}

\author{
M. Yokoe, Y. Ishikawa, M. Nakashima, K. Yoshida, and Y. Kanai* \\ Kogakuin University, 1-24-2 Nishishinjuku, Shinjuku-ku, Tokyo 163-8677, Japan \\ "Niigata Institute of Technology, 1719 Kashiwazakishi, Fujihashi, Niigata 945-1195, Japan
}

\begin{abstract}
Microwave-assisted magnetic recording (MAMR) has recently emerged as a candidate approach to solving the trilemma in magnetic recording. In MAMR, the magnetic recording medium can be switched with a much lower magnetic field by magnetic resonance, which requires an oscillator with a higher frequency than $20 \mathrm{GHz}$. This study, describes a spin-torque oscillator (STO) using a material with a large negative anisotropy that is capable of generating a higher frequency and a stable magnetic field, and shows that it is preferable to a conventional oscillator using soft magnetic materials.
\end{abstract}

Key words: microwave-assisted magnetic recording, spin-torque oscillator, micromagnetic simulation, negative magnetic anisotropy

\section{負の磁気異方性材料を用いたマイクロ波発振素子の検討}

横江真人・石川勇磨・中島正寛・吉田和悦・金井靖*

工学院大学, 東京都新宿区西新宿 1-24-2（广163-8677）

"新潟工科大学, 新潟県柏崎市藤橋 1719（广945-1195）

\section{1. はじめに}

磁気記録では 1Tbits/inch ${ }^{2}$ 以上の高面記録密度を目指し，現在 開発が進められている. その実現のためには媒体雑音と熱摇らぎ, 記録へッドの磁界強度限界の間にあるトリレンマを解決する必要 がある，その解決法の 1 つとして，高周波磁界による磁気共鳴を 用いたマイクロ波アシスト磁気記録(Microwave-assisted Magnetic Recording : MAMR)が注目されている 1).この方式では 磁気ヘッドから発生する記録磁界に直交する面に $\mathrm{GHz}$ オーダー の高周波磁界を重畳し，記録媒体に磁気共鳴を起こさせる．する と大きな磁気異方性をもつ材料を記録媒体に用いてもスイッチン グ磁界を下げることが可能となり，記録へッドの磁界強度限界と 熱摇らぎの問題を解決することが可能となる. この方式では 20 $\mathrm{GHz}$ 以上の高周波磁界で発振する素子(Spin Torque Oscillator : STO)が必要である. MAMR 提案者である J-G. Zhu による従来の STO 構造を Fig.1 の(a)に，D. Houssamedine による 2 層構造を 基にしたSTO 構造を Fig. 1 の(b)にそれぞれ示す. Fig.1 の(a)は 3 層構造, (b)は 2 層構造となっており, 両者にはそれぞれ問題点が ある. 3 層構造では垂直磁化膜層(Perpendicular layer), 軟磁性体 を用いた磁界発生層(Field Generating Layer : FGL), 偏極した電 子を注入するためのリファレンス層(Reference Layer)からなり， 垂直磁化膜層でFGLの磁化を垂直に立たせ，リファレンス層から 注入した逆向きの磁気モーメントをもつ電子と釣り合わせること で磁化の歳差運動を起こす。この構造では $40 \mathrm{GHz}$ 以上の高周波 磁界が得られることが示された ${ }^{2}$. 問題点は垂直磁化膜層に非常に 大きな磁気異方性(10 MJ/m $\mathrm{m}^{3}$ 以上)が必要となるので作製が難しく, またリファレンス層の磁化方向と垂直磁化膜層の磁化方向が互い に向き合っているので, リファレンス層の作製が難しいという 2 点である. また，(b)に示した 2 層構造は FGL とリファレンス層
からなる. Houssamedine の提案では外部磁界を FGL 面内方向に 印加しているのに対し 3), 第 3 章でも述べるが, 外部磁界を垂直 方向に印加しても磁化が歳差運動を起こすことができる. この構 造では垂直磁化膜層が必要ないという利点がある. しかし, 上記 したSTO素子を記録へッドとトレーリングシールド間に設置した 場合 ${ }^{4)}$, 後で指摘するように発振を起こさせるには大きな磁界が 必要となり, 記録へッドのメインポールからの磁界が STO 側に流 れてしまう割合が大きくなってしまう恐れがある.

Field generating layer (FGL)

Perpendicular layer
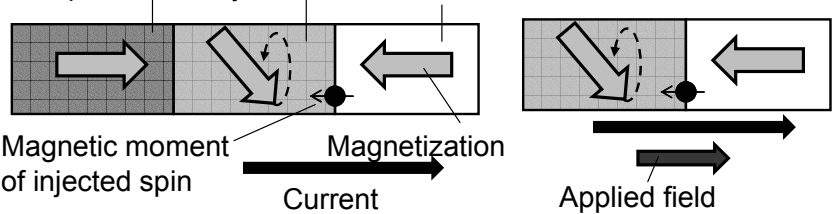

Applied field
(a) 3 layers
(b) 2 layers

Fig. 1 Schematic diagram of a conventional spin-torque oscillator.

そこで我々は上記の問題点を解決できる構造を検討した結果, 垂直磁化膜層を省略した 2 層構造において，FGLに負の大きな磁 気異方性をもつ磁生体を用いれば, $20 \mathrm{GHz}$ 以上の安定した高周波 磁界が得られることを見いだしたので報告する.

\section{2. 計算モデルと計算条件}

Fig.2 にSTO の計算モデルを示す. STO は軟磁性体あるいは大 きな負の磁気異方性をもつ磁性膜からなる FGL とスピンを注入 するリファレンス層で構成される. FGLに偏極したスピンを注入 することにより, FGLの磁化が歳差運動を起こし, 空間に高周波 磁界が発生する. 本計算では FGL の層の厚さd $\mathrm{d} 10 \mathrm{~nm}$, 断面 
を 40×40 nm² の正方形とし, リファレンス層は省略して計算を行 った. 計算領域を 1 辺 $2 \mathrm{~nm}$ の立方体に離散化し，式(1)に示すス ピントルク項を含めた Landau-Lifshitz-Gilbert(LLG)方程式を用 いて FGLの磁化挙動を計算した. FGLから直下 $11 \mathrm{~nm}$ 離れた平 面 $\left(40 \times 10 \mathrm{~nm}^{2}\right)$ を発振磁界の観察面とし，その面平均をとることに よって発振磁界強度とした。

$$
\begin{aligned}
\left(1+\alpha^{2}\right) \frac{d M}{d t} & =-\gamma \vec{M} \times\left(\vec{H}_{e f f}-\alpha \vec{H}_{s t}\right)-\frac{\lambda}{M_{s}} \vec{M} \times \vec{M} \times\left(\alpha \vec{H}_{e f f}+\vec{H}_{s t}\right), \\
\vec{H}_{s t} & =a_{j} \vec{M}_{p}=\frac{\hbar \eta J}{2 e M_{s} d} \vec{M}_{p} .
\end{aligned}
$$

式(1)の $\vec{H}_{s t}$ は偏極したスピンによる磁界を表すべクトルである. スピントルク磁界 $\vec{H}_{s t}$ の方向は単位ベクトル $\vec{M}_{P}$ に一致し, その大 きさは $\mathrm{aj}_{\mathrm{j}}$ で表される. $\vec{M}_{P}$ はリファレンス層の磁化方向を示して おり, Fig.2 座標軸の+ $\mathrm{x}$ 方向を正とする. J は注入電流密度であ り $1.2 \times 10^{12} \sim 7.3 \times 10^{12} \mathrm{~A} / \mathrm{m}^{2}$, ๆはスピン分極率であり 0.5 , ダ ンピング定数 $\alpha$ は 0.02 であり, 時間刻多幅 $\Delta \mathrm{T}$ は $2.0 \times 10^{-14} \mathrm{~s}$ と して計算した. FGL の飽和磁化 $\mathrm{M}_{\mathrm{s}}$ を $2.0 \mathrm{~T}$, 交換定数 $\mathrm{A}$ を $2.0 \times 10^{-11} \mathrm{~J} / \mathrm{m}^{3}$ と固定した. 負の磁気異方性を仮定した場合は, FGLの法線方向を磁化困難軸とし, 異方性定数Kを一 $2 \times 10^{6} \sim-$ $8 \times 10^{6} \mathrm{~J} / \mathrm{m}^{3}$ と変化させた。 また比較のために従来構造の STO(Fig.1 (b))の発振特性も計算したが，その場合は $\mathrm{K}=5 \times 10^{3}$ $\mathrm{J} / \mathrm{m}^{3}$ とし, 磁化容易軸を $\mathrm{y}$ 軸方向に優先配向させた. 以上の条件 のもと, ajを一 $6 \times 10^{4} \sim 6 \times 10^{4} \mathrm{~A} / \mathrm{m}, \mathrm{FGL}$ に印加した外部磁界を 0 $\sim 8 \times 10^{5} \mathrm{~A} / \mathrm{m}$ の範囲で変化させ，発振特性を検討した.

\section{3. 計算結果}

\subsection{FGL に軟磁性体を用いた場合の磁界発振特性}

比較のためにまず従来の $\mathrm{STO}$ 構造である $\mathrm{Ms}=2.0 \mathrm{~T}, \mathrm{~K}=5 \times 10^{3}$ $\mathrm{J} / \mathrm{m}^{3}$ の磁生膜を用いた場合の発振特性を計算する. 断面は $40 \times$ $40 \mathrm{~nm}$, 厚み $10 \mathrm{~nm}$, 印加した外部磁界は $2.0 \times 10^{5} \mathrm{~A} / \mathrm{m}$ である. Fig.2 に示した観察面で発振磁界を平均した結果を Fig3 に示す. Fig.3 は磁界の $\mathrm{x}$ 成分と $\mathrm{y}$ 成分のみを示している. これはへッドの 磁界に対して, 直交寸る成分 $(\mathrm{x}, \mathrm{y}$ 成分)の夕が媒体磁性体膜の磁 気共鳴に寄与するためである. Fig.3 から磁界の振幅值(ピーク対 ピーク值の半分) は約 $60 \mathrm{kA} / \mathrm{m}$ であり, 安定して発振しているこ とがわかる. 次にスピントルク磁界 $\mathrm{H}_{\mathrm{st}}$ と外部磁界 $\mathrm{H}_{\mathrm{apl}}$ が発振状 態にどのような影響を与えるか検討した. Fig.4 にその結果を示し た. この図では, $\mathrm{H}_{\mathrm{st}}$ の極性が振幅特性に与える影響を検討するた め, $\vec{M}_{P}$ の極性を変化させて正負の方向について行った. $\mathrm{H}_{\mathrm{st}}$ の極 性が正の場合, 図に示寸ように $\mathrm{H}_{\mathrm{st}}$ の方向は外部磁界と同じ方向で ある. また, $\mathrm{H}_{\mathrm{st}}$ の極性が負の場合, 外部磁界と逆の方向である. 図中の $(○)$ は安定した発振，( $\triangle$ )はやや安定した発振，(×)はまっ たく発振しない状態を示す. Fig.4 から $\mathrm{H}_{\mathrm{st}}$ の極性が正の範囲では 全く発振しないことがわかる.さらに $\mathrm{H}_{\mathrm{st}}$ の極性が負の範囲では安 定して発振する範用がとても狭く，しかも $20 \mathrm{GHz}$ 以上の発振周 波数を得るには $800 \mathrm{kA} / \mathrm{m}$ 以上の高い外部磁界が必要であること がわかる.

ところで, Fig.3の結果では発振磁界強度の大きさは約 $60 \mathrm{kA} / \mathrm{m}$

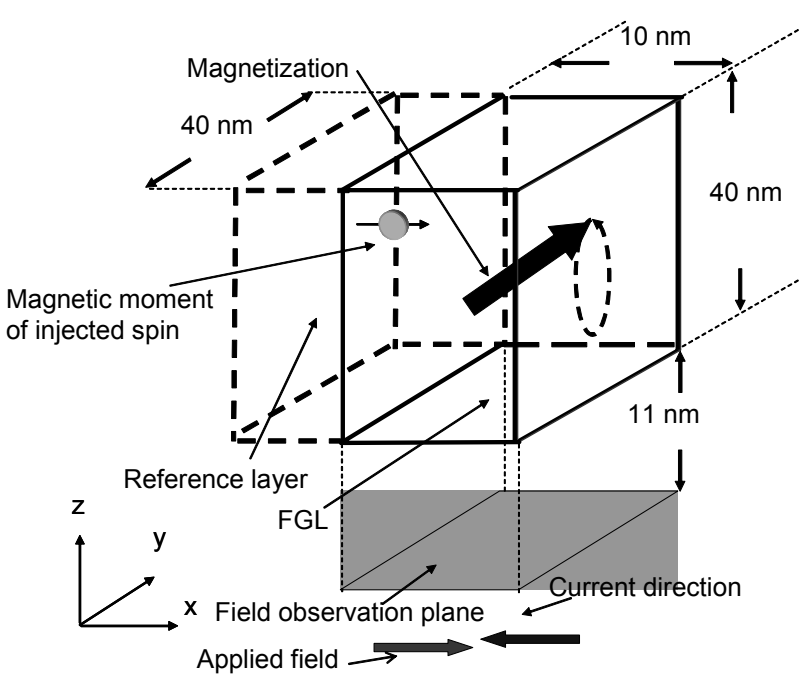

Fig. 2 Schematic diagram of a spin-torque oscillator.

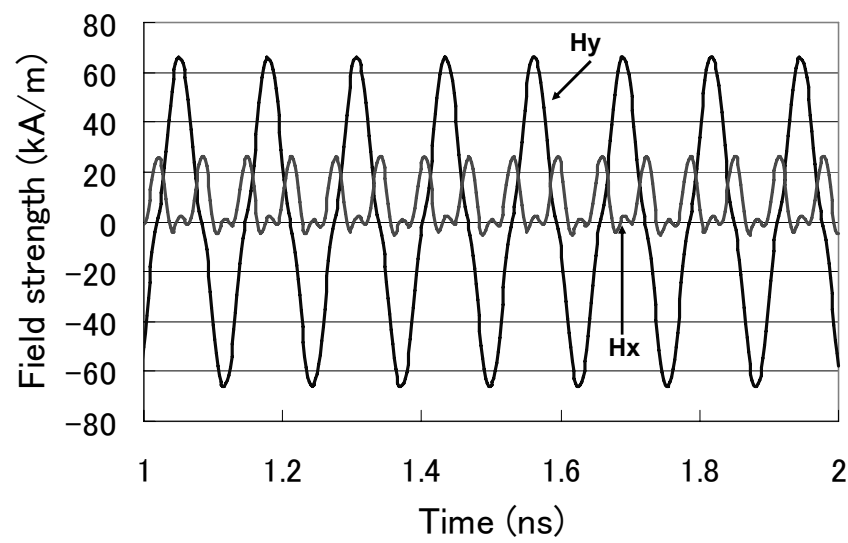

Fig. 3 Oscillating field generated by the FGL with magnetically soft material.

$\mathrm{K}=5 \times 10^{3} \mathrm{~J} / \mathrm{m}^{3}, \mathrm{~A}=2.0 \times 10^{-11} \mathrm{~J} / \mathrm{m}, \mathrm{H}_{\mathrm{apl}}=2.0 \times 10^{5} \mathrm{~A} / \mathrm{m}$, $\mathrm{H}_{\mathrm{st}}=-2.0 \times 10^{4} \mathrm{~A} / \mathrm{m}$, spacing $11 \mathrm{~nm}$.

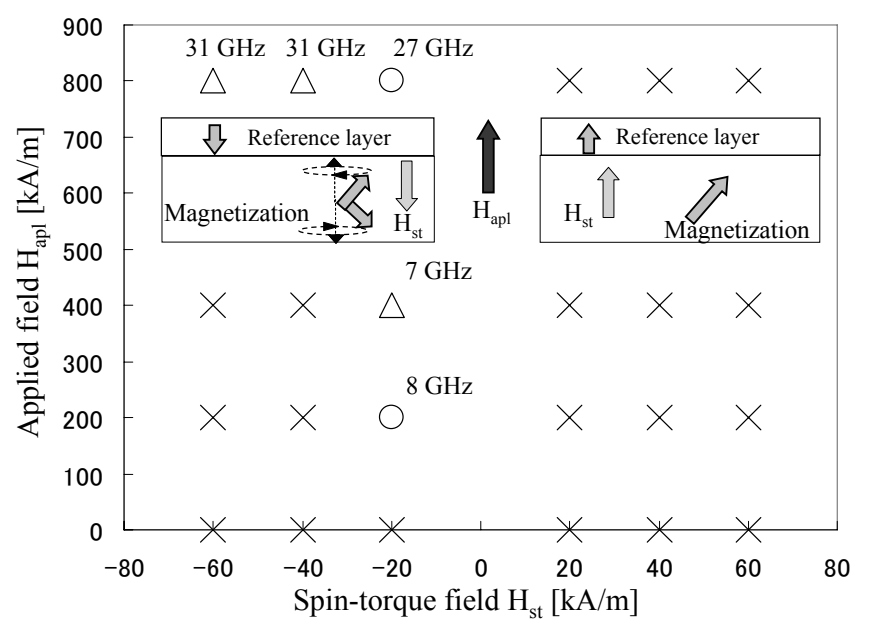

Fig. 4 Phase diagram of oscillation behaviors with magnetically soft material.

$\mathrm{K}=5 \times 10^{3} \mathrm{~J} / \mathrm{m}^{3}, \quad \mathrm{~A}=2.0 \times 10^{-11} \mathrm{~J} / \mathrm{m}$.

と磁気共鳴を起こすために不足している，そこで，観察面におけ る磁界成分Hyの分布を調べた. その結果をFig.5に示す.ただし, この例では Fig.3 に示した極大值における磁界強度分布であり, 
spacing は $11 \mathrm{~nm}$ である. 磁界強度 $120 \mathrm{kA} / \mathrm{m}$ 以上の領域は観察 面の中心 $12 \mathrm{~nm}$ の幅で得られている. 以上のように軟磁性体を用 いた場合の磁界強度は $120 \mathrm{kA} / \mathrm{m}$ 以上の高い值が得られることが 分かった. しかし, 発振周波数に着目すると Fig.3 に示すように $8 \mathrm{GHz}$ ほどしか得られない. $20 \mathrm{GHz}$ 以上を得るには，Fig.4に示 すように $800 \mathrm{kA} / \mathrm{m}$ 以上の大きな外部磁界 $\mathrm{H}_{\mathrm{apl}}$ が必要となる.こ の場合， STO に強い磁界を印加させるために，記録へッドのメイ ンポールとトレーリングシールド間に STO 素子を設置し, メイン ポール先端に流入する磁束の一部をSTO側に分流させる必要がで てくる. このことは，本来記録媒体に流入させるべき磁束が減少 することを意味しており，記録磁界が弱くなる恐れがある．以上 述べた様に図 1 (b)の示した従来構造のSTO をMAMRに適用させ るには，種々の問題を解決寸る必要がある，そこで，これらの問 題を解決するため次節において負の磁気異方性材料を適用した STO 素子の提案を行う.

\section{3. $2 \mathrm{FGL}$ に負の磁気異方性材料を用いた場合の磁界発振特}

\section{性}

高周波磁界を得るため, STO 素子の FGL 部に負の磁気異方性 材料を用いることを試みた．その理由は以下のようである．第 4 章で説明するように，軟磁性体膜を用いた従来の STO では，歳差 運動を起こさせるには FGL 膜面から磁化を立ち上げた時に生じ る反磁界 $\left(\mathrm{H}_{\mathrm{d}}\right)$ と印加磁界の差(実効磁界 $\left.\mathrm{H}_{\mathrm{eff}}\right)$ と注入スピントルク磁 界 $\left(\mathrm{H}_{\mathrm{st}} \mathrm{\alpha}\right)$ をバランスさせる必要がある. 発振周波数は $\mathrm{H}_{\mathrm{eff}}$ に比例す るため, 発振周波数はおおむ水 FGLの飽和磁化 $\mathrm{M}_{\mathrm{s}}$ で制限される. したがって，実効磁界 $\mathrm{H}_{\mathrm{eff}}$ を増大させるためには膜面に大きな磁 気異方性を持たせることが考えられるが, 1 軸異方性の磁化容易軸 を面内に向けると，面内に大きな異方性がつくため, 磁化の回転 運動に対して障害となることが予想される. これに対して負の 1 軸磁気異方性を用いて，その困難軸を膜面垂直方向に向ければ， 面内が磁化容易面となり，回転を阻害することなく実効的に大き な $\mathrm{H}_{\mathrm{eff}}$ を持たせることが期待できる. また，文献 5，6，7 に示し たように負の磁気異方性の材料は既知であり，本報告では，この 磁気異方性材料の STO への応用の可能性につき検討した.

Fig.6 に $\mathrm{Ms}=2.0 \mathrm{~T}, \mathrm{~K}=-2.0 \times 10^{6} \mathrm{~J} / \mathrm{m}^{3}$ とした場合の平均磁 界強度の経時変化を示す. Fig.6 から磁界の発振周波数は $13 \mathrm{GHz}$ と $10 \mathrm{GHz}$ を容易に超えることが出来る.この結果は負の磁気異 方性材料は高い発振周波数を得る材料として有効であることを示 している. また観察面で得られた磁界成分 Hy の分布を Fig.7 に示 寸. この例は Fig.6 の最大值における磁界強度分布であり，その最 大磁界強度は $120 \mathrm{kA} / \mathrm{m}$ と Fig.5 に示した軟磁生体の磁界強度と 比べ若干減少しているが，120 kA/m 以上の領域は直径 $10 \mathrm{~nm}$ を 超える範囲に及んでいる. 次に磁性体の磁気異方性定数 $\mathrm{K}$ を変化 させ, 発振周波数との関係を調べ結果を Fig.8 に示す. 異方性定数 の絶対值が大きくなるにともない，発振周波数も高くなることが わかる. そこで, 発振周波数 $20 \mathrm{GHz}$ が得られる $\mathrm{K}=-6 \times 10^{6}$ $\mathrm{J} / \mathrm{m}^{3}$ においてさらに詳細な計算を行った. スピントルク磁界と外 部磁界の関係を調べた結果を Fig.9 に示す. Fig.9 から見て分かる ように，Fig.4に示した従来の軟磁生膜を用いた FGL と比較し，

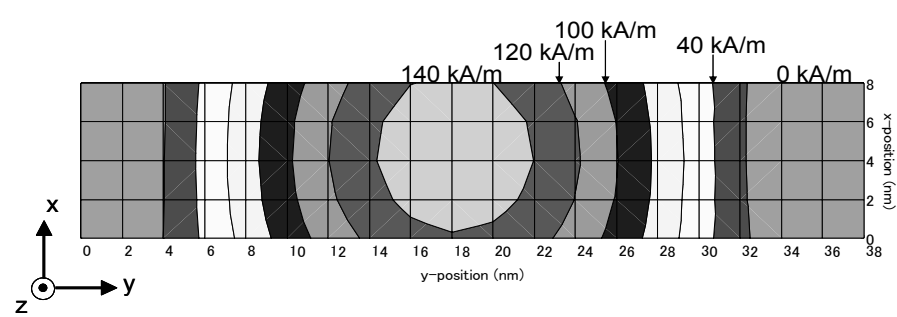

Fig. 5 y component Field distribution at positive peak. $\mathrm{K}=5.0 \times 10^{3} \mathrm{~J} / \mathrm{m}^{3}, \quad \mathrm{Hapl}=2.0 \times 10^{5} \mathrm{~A} / \mathrm{m}$,

$\mathrm{H}_{\mathrm{st}}=-2.0 \times 10^{4} \mathrm{~A} / \mathrm{m}, \mathrm{t}=1.05 \mathrm{~ns}$.

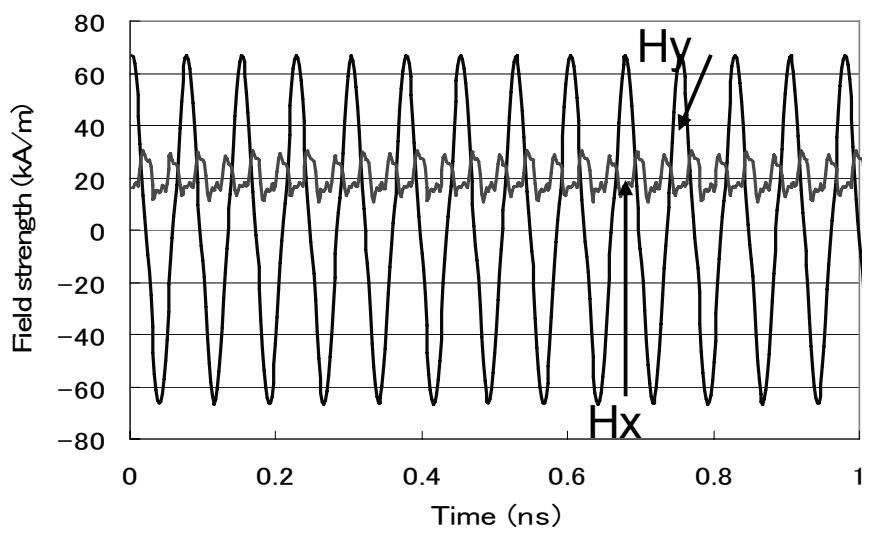

Fig. 6 Oscillating field generated by the FGL with negative anisotropy magnetic material.

$\mathrm{K}=-2.0 \times 10^{6} \mathrm{~J} / \mathrm{m}^{3}, \mathrm{H}_{\mathrm{apl}}=0 \mathrm{~A} / \mathrm{m}, \mathrm{H}_{\mathrm{st}}=-4.0 \times 10^{4} \mathrm{~A} / \mathrm{m}$.

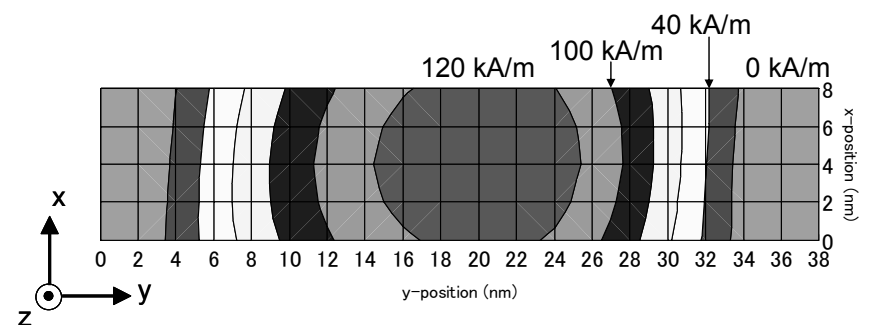

Fig. 7 y component Field distribution at positive peak. $\mathrm{K}=-2.0 \times 10^{6} \mathrm{~J} / \mathrm{m}^{3}, \mathrm{Hapl}=0 \mathrm{~A} / \mathrm{m}, \mathrm{H}_{\mathrm{st}}=-4.0 \times 10^{4} \mathrm{~A} / \mathrm{m}$, $\mathrm{t}=0.078 \mathrm{~ns}$.

安定して発振する範囲がきわめて広くなることがわかる. しかも スピントルク磁界 $\mathrm{H}_{\mathrm{st}}$ が正と負の両方の極性で発振することが分 かった. さらに $\mathrm{H}_{\mathrm{st}}$ の絶対值を大きくすることで, 発振周波数も高 くなることがわかる. 発振周波数に着目すると, 外部磁界を 800 $\mathrm{kA} / \mathrm{m}$ まで増加させてもあまり影響がないので, $\mathrm{H}_{\mathrm{apl}}$ の依存性は少 ないことがわかる．また $\mathrm{H}_{\mathrm{apl}}$ が $0 \mathrm{kA} / \mathrm{m}$ でも発振可能であること もわかった. 発振周波数とスピントルク磁界の関係を調べた結果 を Fig.10に示す．スピントルク磁界がある一定值に達しないと， 発振がおこらないことが分かる. また $\mathrm{H}_{\mathrm{st}}$ の極性は発振周波数増加 の効率にそれほど影響しないことが分かる. このように, $\mathrm{H}_{\mathrm{st}}$ の極 性に関係なく発振させることが可能なため, Fig. 9 に示したように, 外部磁界とリファレンス層の磁化を同じ向きにすることができる ためMAMR 用記録ヘッドの作製が容易になる. Fig.4 に示した軟 磁性体の場合, $\mathrm{H}_{\mathrm{st}}$ の極性が正では全く発振しないことと比較する と, 負の大きな磁気異方性をもつ磁性体を用いた場合の大きな特 
長点となる.

なお負の磁気異方性をもつ材料は, 以下が既に知られている.

1) Co0.8Iro.2 (ABAC hexagonal) : $\mathrm{K}=-0.6 \times 10^{6} \mathrm{~J} / \mathrm{m}^{3}$ 5).

2) $\mathrm{Co}_{0.99} \mathrm{Fe}_{0.01}: \mathrm{K}=-0.99 \times 10^{6} \mathrm{~J} / \mathrm{m}^{3}$ 6).

3) $\mathrm{Fe} / \mathrm{Co}$ multilayer : $\mathrm{K}=-1.1 \times 10^{6} \mathrm{~J} / \mathrm{m}^{3}$ 7).

負の磁気異方性の絶対值は MAMR 素子の適用には不足している が，この材料に関してはまだ材料開発が進められておらず，今後 の材料研究で新たな材料が開発されることを期待する.

\section{4. 考察}

以上述べた結果の一部は次に示す簡単な計算で定性的に説明で きる. 磁化の挙動は式(1)より解析でき, 第 1 項は歳差項, 第 2 項 は制動項である. MAMR は磁化の歳差運動によって振動磁界が生 じるので, 制動項が 0 にならなくてはならない．磁化分布が一様 であると仮定すると, 式(1)の制動項が 0 になる条件は式(2)となる.

$$
H_{\text {eff }}+\frac{H_{s t}}{\alpha}=0
$$

発振周波数 $\mathrm{f}_{\mathrm{r}}$ は, 式(1)の第 1 項から式(3)により表せる.

$$
\begin{aligned}
f_{r} & =\frac{\gamma}{2 \pi} \frac{\left(H_{e f f}-\alpha H_{s t}\right)}{\left(1+\alpha^{2}\right)}=\frac{\gamma}{2 \pi} H_{e f f} \\
& =-\frac{\gamma}{2 \pi \alpha} H_{s t .}
\end{aligned}
$$

ここで $\gamma$ はジャイロ磁気定数であり,$\quad \gamma=2.21 \times 10^{5} \mathrm{~m} / \mathrm{A} \cdot \mathrm{s}$ であ る. 式(3)から発振周波数は実効磁界 $\mathrm{H}_{\mathrm{eff}}$ またはスピントルク実効 磁界 $\mathrm{H}_{\mathrm{st}}$ に比例することが分かる. さらに Fig.11に記した各種磁 界の方向の関係から実効磁界 $\mathrm{H}_{\mathrm{eff}}$ は式(4)で表せる.

$$
\begin{aligned}
H_{e f f} & =H_{d}+H_{k} \sin \Theta+H_{a p l}, \\
H_{d} & =-\frac{M_{s}}{\mu_{0}} \sin \Theta .
\end{aligned}
$$

ここで, $H_{d}$ は反磁界, $\theta$ は膜面から計った磁化の傾き角度であり, 磁化が $\mathrm{x}$ 軸正方向に向かって回転する方向を正とする. $\mathrm{H}_{\mathrm{k}}$ は異方 性磁界であり，膜面内に磁化容易軸(容易面)がある時に負の值とな るものとする. $\mu_{0}$ は真空の透磁率である. 式(2)と式(4)から磁化 の傾き $\theta$ を表す式(5)が得られる.

$$
\Theta=\sin ^{-1}\left[\left(H_{a p l}+H_{s t} / \alpha\right) /\left(M_{s} / \mu_{0}-H_{k}\right)\right] .
$$

式(5)を用いれば, 磁化の傾き $\theta$ を求めることが出来, さらにそ の $\theta$ を式(4)に代入すれば実効磁界が得られる. その実効磁界を式 (3)に代入することで発振周波数 $\mathrm{f}_{\mathrm{r}}$ が求まる.

以上の式を用いた方法で求めた, 外部磁界と磁化の傾き $\theta$ 及び 発振周波数の関係をTab. 1 と Tab. 2 に示した. Tab. 1 に軟磁性体 膜を用いてスピントルク磁界 $\mathrm{H}_{\mathrm{st}}$ の極性が負の場合を, Tab. 2 に負 の磁気異方性をもつ磁性体膜を用いて $\mathrm{H}_{\mathrm{st}}$ の極性が負の場合の計 算結果を示寸. 両表からスピントルク磁界 $\mathrm{H}_{\mathrm{st}}$ を一定に保つ限り, 外部磁界を増大させても発振周波数は変化せずに, その影響は磁 化の傾き角度に現れることが理解できる. この傾向は Fig. 9 に示

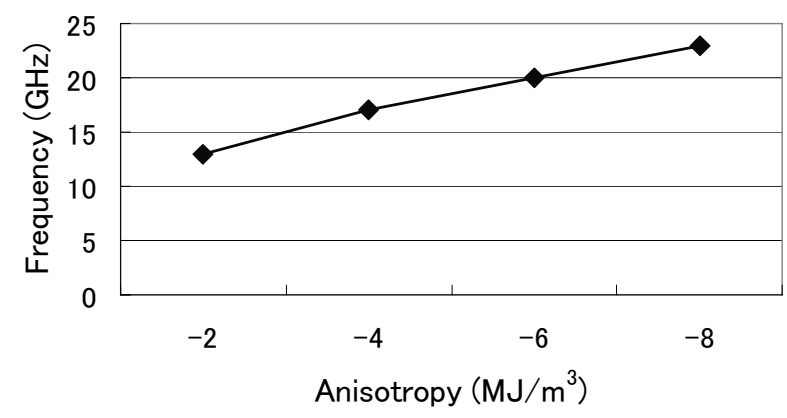

Fig. 8 Relationship between the frequency and the anisotropy constant. $\mathrm{H}_{\mathrm{apl}}=0 \mathrm{~A} / \mathrm{m}, \mathrm{H}_{\mathrm{st}}=-4.0 \times 10^{4} \mathrm{~A} / \mathrm{m}$.

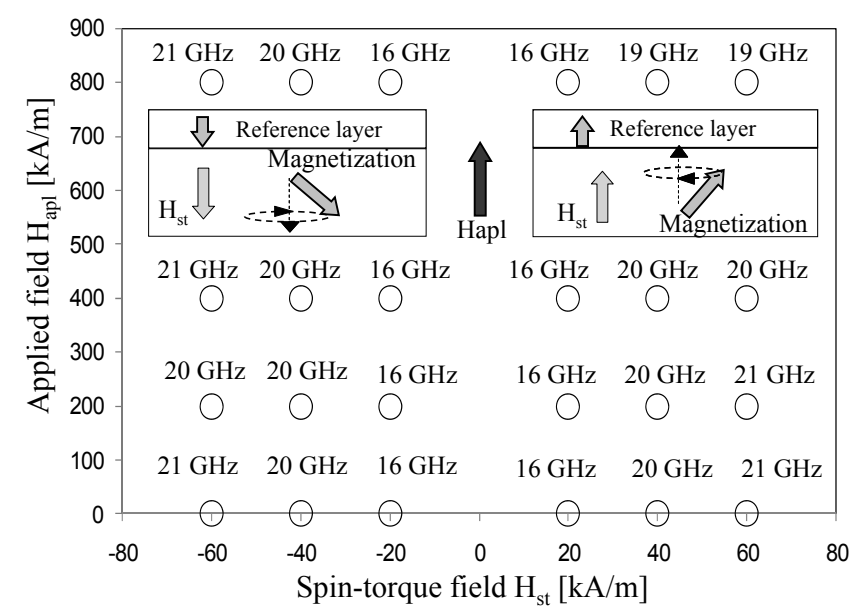

Fig. 9 Phase diagram of oscillation behaviors with negative anisotropy. $\mathrm{K}=-6.0 \times 10^{6} \mathrm{~J} / \mathrm{m}^{3}, \quad \mathrm{~A}=2.0 \times 10^{-11} \mathrm{~J} / \mathrm{m}$.

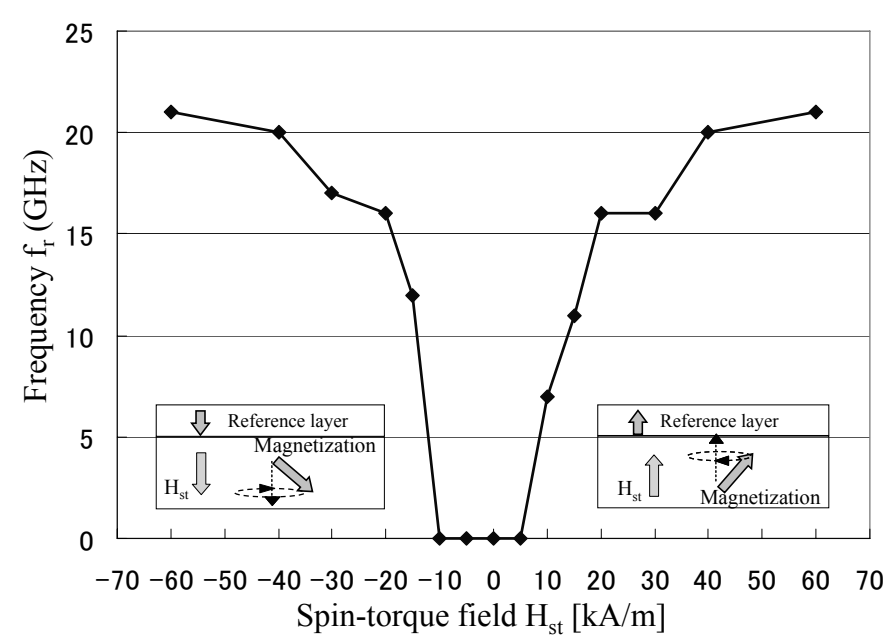

Fig. 10 Oscillating frequency vs $\mathrm{H}_{\text {st. }}$. $\mathrm{K}=-6 \times 10^{6} \mathrm{~J} / \mathrm{m}^{3}, \mathrm{H}_{\mathrm{apl}}=0 \mathrm{~A} / \mathrm{m}$.

した負の磁気異方性をもつ磁性材料を用いた時の, 発振周波数が 外部磁界に依存しないことを説明している. しかし, 軟磁性材料 を用いた場合, 外部磁界に対して強い依存性があることを説明で きない，その理由はまだ明らかでないが，おそらく式(4)に含まれ る異方性磁界の值 $\mathrm{H}_{\mathrm{k}}$ の值が影響しているのではないかと考えら れる. 軟磁性体と負の磁気異方性材料の $\mathrm{H}_{\mathrm{k}}$ を比べると、軟磁生体 の場合は $10^{3} \mathrm{~A} / \mathrm{m}$, 負の大きな磁気異方性をもつ材料の場合は $10^{6}$ 
$\mathrm{A} / \mathrm{m}$ であり，異方性磁界 $\mathrm{H}_{\mathrm{k}}$ が 3 桁ほど違う。そのため軟磁性体 では $\mathrm{H}_{\mathrm{k}}$ が小さいので, Tab. 1 に示した外部磁界変化による磁化の 傾き角度 $\theta$ が大きく変化する. これにより磁化分布が変わるので, 軟磁性体を用いた場合，外部磁界が変化することで発振周波数 $\mathrm{f}_{\mathrm{r}}$ が大きく変化すると推定する。

一方，発振周波数 $\mathrm{f}_{\mathrm{r}}$ について着目寸ると，負の磁気異方性材料 を用いた場合でも, LLG 方程式で計算した $\mathrm{f}_{\mathrm{r}}$ と式(2)〜式(5)で計算 した $\mathrm{f}_{\mathrm{r}}$ は一致しない.これはLLG 方程式で計算した結果を用いて 磁化を可視化すると，磁化分布が非一様であり，歳差運動中の磁 化が回転途中で時々止まる瞬間を観察できた. 式(2)〜式(5)は磁化 分布が一様であり，磁化の回転はなめらかであることを前提とし ている. よって，この磁化の回転が止まる現象が，LLG 方程式か ら得られた発振周波数と式(3)から得られた発振周波数に不一致を 生じさせていると考えられる。逆にこの原因を明らかにすれば, 発振周波数を向上させる手がかりが得られることが期待できる.

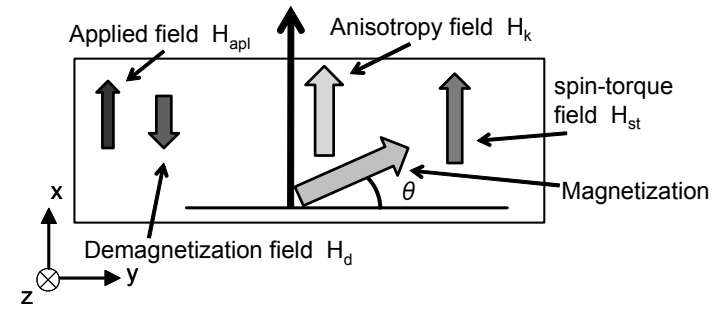

Fig. 11 Description of various effective magnetic fields.

Table 1 Angle and oscillating frequency of magnetization. $\mathrm{K}=5 \times 10^{3} \mathrm{~J} / \mathrm{m}^{3}, \quad \mathrm{H}_{\mathrm{st}}=-2 \times 10^{4} \mathrm{~A} / \mathrm{m}$. (soft magnetic material).

\begin{tabular}{|c|l|c|}
\hline $\begin{array}{c}\text { Applied field } \\
\mathrm{H}_{\mathrm{apl}}[\mathrm{A} / \mathrm{m}]\end{array}$ & $\theta\left[^{\circ}\right]$ & $\begin{array}{l}\text { Oscillating frequency } \\
\mathrm{fr}_{\mathrm{r}}[\mathrm{GHz}]\end{array}$ \\
\hline 0 & -39 & 35 \\
\hline $4 \times 10^{5}$ & -22 & 35 \\
\hline $8 \times 10^{5}$ & -7 & 35 \\
\hline
\end{tabular}

Table 2 Angle and oscillating frequency of magnetization. $\mathrm{K}=-6 \times 10^{6} \mathrm{~J} / \mathrm{m}^{3}, \mathrm{H}_{\mathrm{st}}=-2 \times 10^{4} \mathrm{~A} / \mathrm{m}$. (negative anisotropy magnetic material)

\begin{tabular}{|c|l|c|}
\hline $\begin{array}{c}\text { Applied field } \\
\mathrm{H}_{\mathrm{apl}}[\mathrm{A} / \mathrm{m}]\end{array}$ & $\theta\left[^{\circ}\right]$ & $\begin{array}{l}\text { Oscillating frequency } \\
\mathrm{f}_{\mathrm{r}}[\mathrm{GHz}]\end{array}$ \\
\hline 0 & -7.6 & 35 \\
\hline $4 \times 10^{5}$ & -4.5 & 35 \\
\hline $8 \times 10^{5}$ & -1.5 & 35 \\
\hline
\end{tabular}

\section{5. まとめ}

MAMR 方式記録へッド用の STO 素子の材料として負の磁気異 方性を用いることを試み，その磁界発振特性についてマイクロマ グネティックモデルを用いた数值計算により検討を行い，以下の 結果を得た.

1）負の高磁気異方性の磁性体を MAMR 用の STO 素子に用いる ことで $20 \mathrm{GHz}$ 以上で安定して発振する高周波磁界が得られる.

2）上記素子では, 発振条件への外部磁界の影響が少なく, 外部磁 界とリファレンス層の磁化方向が同じでも発振を起こすことが可 能なためMAMR 用記録へッドの作製を容易にすることができる.

3）負の磁気異方性をもつ材料としては Fe-Co と Co-Ir が知られ ている程度であり, かつ $6 \times 10^{6} \mathrm{~J} / \mathrm{m}^{3}$ のオーダーの材料はまだ存 在しないため材料開発を並行して行う必要がある.

\section{謝辞}

スピントルク計算の手法につきご教示頂いた，日立製作所基礎 研究所の市村雅彦様に感謝いたします。この研究の一部は, スト レージ研究促進機構(Storage Research Consortium ; SRC)及び NEDO(New Energy and Industrial Technology Development Organization), グリーン IT プロジェクトの支援により行われた ものです.

\section{References}

1) J- G. Zhu, X. Zhu, and Y. Tang, "Microwave Assist Magnetic Recording, ”IEEE Trans. Magn. Vol.44, no.1,pp.125 -131(2008). 2) X. Zhu and J-G. Zhu, "Bias-Field-Free Microwave Oscillator Driven by Perpendicularly Polarized Spin Current," IEEE Trans. Magn. Vol.42, no.10, pp.2670 - 2672(2006).

3) D. Houssamedine, et al., "Spin-torque oscillator using a perpendicular polarizer and a planar free layer," nature materials, Vol. 6, pp. 447-453, June, 2007.

4) Y. Tang, and J.G Zhu, "Narrow Track Confiement by AC Field Generation Layer in Microwave Assisted Magnetic Recording” IEEE Trans. Magn. Vol.44, no. 11, pp. 3376 - 3379 (2008).

5) A.Hashimoto, S.Saito, and M.Takahashi, "Proposal for the Use of soft Magnetic Material with negative Uniaxial Magnetocrystalline Anisotropy as an SUL to Suppress both WATE and Spike Noise" J. Magn. Soc. Jpn.Vol.30 , pp135-140(2006).

6) S. Chikazumi, K. Ohta, K. Adachi, N. Tsuya, Y. Ishikawa: Jiseitai Hand Book (in Japanese), (Asakura Syoten, Tokyo, 1982).

7) S.Okamoto, T. Shinozaki, T. Yamashita, N. Kikuchi, and O. Kitakami, "Large magnetic anisotropy in epitaxially grown $\mathrm{Fe} /$ Co multilayer and alloy films," (in Japanese) Dig. 33 $3^{\text {rd }}$ Annu. conf. Magnetics Japan, 2009, p. 62.

2009年10月20日受理，2010年5月20日採録 